\title{
Socio-demographic Determinants of Hypovitaminosis D
}

\author{
Rahman $\mathrm{AHMH}^{1}$, Zafreen $\mathrm{F}^{2}$, Nazneen $\mathrm{L}^{3}$, Wahab $\mathrm{MA}^{4}$
}

DOI: https://doi.org/10.3329/jafmc.v14i2.45902

\section{Abstract}

Introduction: Hypovitaminosis D is a silent butvery devastating health issue throughout the world. Socio-demographic factors have some role on the issue.

Objectives: To determine the sociodemographic determinants of hypovitaminosis $\mathrm{D}$ among the clients attending specialized hospitals.

Materials and Methods: This cross-sectional study was conducted among 264 respondents attended the Armed Forces Institute of Pathology, Dhaka Cantonment for estimation of 25(OH) D within the period of July 2017 to June 2018.

Results: Respondentsmeanage was $48.23 \pm 14.05$ years and themajority $(68.56 \%)$ were female among themhalf $(49.72 \%)$ were menopausal. All the clients were educated and majority $(68.18 \%)$ had crossed the level of higher secondary. The mean \pm SD of monthly family income was Taka $68824.46 \pm 23.92$ and majority $(57.57 \%)$ were from higher socioeconomic group. A large portion $(47.35 \%)$ of the respondents was housewives followed by (26.56\%) government employee. The mean \pm SD level of $25(\mathrm{OH})$ D of total population was $50.01 \pm 29.93 \mathrm{nmol} / \mathrm{L}$ butamong the male and female it was $50.86 \pm 28.61 \mathrm{nmo} / \mathrm{L}$ and $49.60 \pm 26.19 \mathrm{nmol} / \mathrm{L}$ respectively. Menopausal women $(48.03 \pm 28.11 \mathrm{nmol} / \mathrm{L})$ had significantly $(p<0.05)$ less vitamin $D$ than non-menopausal women $(52.32 \pm 23.96 \mathrm{nmol} / \mathrm{L})$ butupper-income group $(52.47+23.12$ $\mathrm{nmol} / \mathrm{L})$ found significantly $(p<0.05)$ higher vitamin $D$ than lower socioeconomic group $(46.32+16.78 \mathrm{nmol} / \mathrm{L})$. The fare skinned respondents $(54.46+28.24 \mathrm{nmol} / \mathrm{L}))$ had significantly $(\mathrm{p}<0.01)$ higher level of vitamin $D$ than dark-skinned persons $(42.59+16.79$ $\mathrm{nmol} / \mathrm{L})$. The overall hypovitaminosis $\mathrm{D}$ was $84.84 \%$.

Conclusion: The prevalence of hypovitaminosis $D$ was too high and sociodemographic determinants have a significant impact on vitamin D level. Effective measures need to be taken at all level to overcome nutritional disorder.

Key-words: Vitamin D, Socio-demographic determinants, Sunlight.

\section{Introduction}

Vitamin D deficiency is common worldwide irrespective of its occurrence in both high and low-latitude countries. In addition to the European countries, vitamin $D$ deficiency has been reported in many countries in the Middle East, Africa and Asia. Surprisingly, it is more frequent in the sunny Mediterranean countries than in certain northern countries such as Norway. A high prevalence of vitamin $D$ deficiency, low dietary intake of calcium was observed in premenopausal Bangladeshi women of both high and low socioeconomic statuses. Their lifestyle largely confining them to the home and the traditional clothing that Bangladeshi women wear exposes very little of their skin to sunlight. Under these conditions, women in different groups are at risk of developing vitamin $D$ deficiency ${ }^{1}$. Despite ample amount of sunshine in Bangladesh vitamin $D$ deficiency is present in a sizeable share of the general population which in itself seems to be a paradox ${ }^{2}$. This sub-continent receives plenty of sunshine all year round and thus people in this area should not lack vitamin D. An insufficient exposure to sunlight is the main cause of vitamin $D$ deficiency ${ }^{3}$. With the achievement in increasing life expectancy, issues originated from vitamin $D$ deficiency is also playing serious role in our daily life. Though many of our population are suffering from different types of problem including unusual pain, there is very less study conducted on this topic in Bangladesh. With this proposal, this study tried to explore some key sociodemographic determinants of vitamin $D$ of public health interest. Determinants are:

Skin pigmentation-many factors reduce the skin's production of vitamin $\mathrm{D}^{3}$, including increased skin pigmentation, ageing, and the sun protection behaviours such as application of a sunscreen or cover most part of their bodies with clothes ${ }^{4}$. Vitamin $D$ synthesis is highly dependent on the concentration of melanin in the skin as melanin absorbs and scatters UVR-B, resulting in a less efficient conversion of 7-dehydrocholesterol to pre-vitamin $D^{35}$. Therefore, dark-skinned individuals will experience slower vitamin $\mathrm{D}$ synthesis than light-skinned ones ${ }^{6}$.

Age-in general, the cutaneous production of vitamin $\mathrm{D}$ declines with age $\mathrm{e}^{7}$. Elderly usually stay indoors for prolong periods of time and have limited physical activity due to multiple comorbidities, which further contribute to less sun exposure. Interestingly, elderly in Southeast Asia such as Thailand and Korea have a better vitamin $D$ status when compare with younger people. The possible explanation is these elderly have more free time and spend time doing outdoor activities ${ }^{8}$.

1. Lt Col Abu Hasanat Md Habibur Rahman, MBBS, MPH, MPhil, Commanding Officer, CMH, Momenshahi (E-mail: habib03r@gmail.com) 2. Dr Farzana Zafreen, MBBS, MPH, Associate Professor \& Head, Department of Community Medicine, Medical College for Women and Hospital, Uttara, Dhaka.3. Lt Col Lubna Nazneen, MBBS, DCP, MCPS, FCPS, Classified Specialist in Pathology, AFIP, Dhaka 2. Lt Col Md Abdul Wahab, MBBS, MD, Associate Professor of Biochemistry, AFMC, Dhaka. 
Gender- higher level of vitamin D is found among the female population than male same geographical and cultural areas,especially in western countries. But the situation was reversed in Muslim countries or the area where women put on cloths covering whole body ${ }^{2}$. Women have often many potential factors for having lower level of Vitamin D. Those are composition of body fat, less exposed to sunlight, less chance of physical activity, dietary constrain in country like Bangladesh ${ }^{9}$. Menopausal state- age is a crucial factor in determining cutaneous synthesis of vitamin D. Ageing affects multiple steps of vitamin $\mathrm{D}$ metabolism as ageing skin has reduced efficiency to synthesize vitamin $\mathrm{D}$ upon exposure to $\operatorname{sun}^{10}$. Therefore, post-menopausal women are more vulnerable to vitamin $D$ deficiency owing to their inevitable ageing process coupled with obesity. Religion and cultural behaviour- the variation of vitamin $D$ status in people who live in the same city or country is partly linked to religious, lifestyle and nutritional difference. There was a report that only onethird of participants were vitamin $D$ sufficient $[25(\mathrm{OH}) \mathrm{D} \geq 50$ $\mathrm{nmol} / \mathrm{L}]$ in Malaysia which is a tropical country located at the equator and is sunny all year round. Most of the populations are Muslim. It's not surprising that the lower 25(OH)D levels were found in females, explained by the tradition costume (wearing long sleeves, long skirts and veil) ${ }^{11}$. Air pollutionthe pollutants present in our surroundings efficiently absorbs UVB radiation and thus reduces the amount that reaches the earth's surface. This phenomenon may partially explain why residents of big cities such as Bangkok (Thailand), Delhi (India) had the lowest $25(\mathrm{OH}) \mathrm{D}$ concentration when compared with other cities/area in those countries ${ }^{12}$. Latitude and seasoncountries near to the equator receive more sunlight all year round compare with those far from the equator. In this area people are supposed to have better level of vitamin $D^{13}$.

\section{Materials and Methods}

A cross-sectional study was carried out to identify the sociodemographic determinants of Hypovitaminosis D. A total of 264 young adults were enrolled fromJuly 2017 to June 2018 from the Biochemistry laboratory of AFIP. Information on sociodemographic factors including education and income were obtained by self-reported questionnaires. Vitamin $D$ level was categorized as Sufficient ( $\geq 75 \mathrm{nmol} / \mathrm{L})$, Insufficient (50-74 nmol/L), Deficient (25-49 nmol/L) and Severe Deficient ( $<25 \mathrm{nmol} / \mathrm{L}$ ). Any value less than $75 \mathrm{nmol} / \mathrm{L}$ considered ashypovitaminosis $D$ for this study. Ethical clearance of the study was approvedbylnstitutional Review Board of NIPSOM. Written permission was taken from appropriate authority ofNIPSOM and AFIP. The respondents were briefed about the purpose of interview and written consent was taken.Data were analyzed by SPSS version 23 . Statistical significance was done by chi-square test, One-way ANOVA and t-Test in specific issues.

\section{Results}

A total of 264 clients were interviewed among the reported for $25(\mathrm{OH}) \mathrm{D}$ estimation. The study revealed the following findings with respect to socio-demographic characteristics of the respondents (Table-I). In this study, 40(15.16\%) was found having sufficient level of vitamin D, Total $63(23.86 \%)$ was found insufficient, $129(48.86 \%)$ was deficient and 32(12.12\%) were found having severely deficient. Total hypovitaminosis D proportion was 224(84.84\%) (Figure-2). The mean level of vitamin $D$ was clearly different between two groups of same variable. Male had slightly raised vitamin $\mathrm{D}$ level than female. Menopausal women had less vitamin D level than that of reproductive age. Respondents living in dusty area had lower level of vitamin $\mathrm{D}$ than those living in dust-free area. Persons working in outdoor had higher level of vitamin $D$ than those working at office or indoor area. Most of the findings are statistically significant $(p<0.05)$ (Table-II). Hypovitaminosis $D$ was highest $(97.3 \%)$ among the respondents living in industrial area. It was lowest (80.7\%) among the city dwellers. This association was statistically significant $(p<0.05)$ (TableIII). Among fare complexion respondents, vitamin $D$ was significantly $(p<0.01)$ higher $(54.46 \mathrm{nmol} / \mathrm{L})$ than that of darkskinned respondents (42.59 nmol/L) (Table-IV).

Table-I: Socio-demographic factors of the respondents

\begin{tabular}{|l|l|r|r|}
\hline \multirow{2}{|c|}{ Variable } & \multicolumn{1}{|c|}{ Group } & Frequency & Percentage \\
\hline \multirow{2}{*}{ Gender } & Male & 83 & 31.44 \\
\cline { 2 - 4 } & Female & 181 & 68.56 \\
\hline \multirow{4}{*}{ Eeligion } & Muslim & 251 & 95.00 \\
\cline { 2 - 4 } & Non- Muslim & 11 & 5.00 \\
\hline \multirow{4}{*}{ Marital status } & SSC & 84 & 31.82 \\
\cline { 2 - 4 } & HSC & 67 & 25.28 \\
\cline { 2 - 4 } & Graduate & 75 & 28.78 \\
\cline { 2 - 4 } & Postgraduate & 38 & 14.0 \\
\hline \multirow{2}{*}{ Menopausal state (F) } & Married & 214 & 81.06 \\
\cline { 2 - 4 } & Unmarried & 19 & 7.20 \\
\cline { 2 - 4 } & Widow/widower & 27 & 10.22 \\
\cline { 2 - 4 } & Separated & 4 & 1.56 \\
\hline \multirow{2}{*}{ Age (years) Mean \pm SD: } & Menopausal & 90 & 49.72 \\
\cline { 2 - 4 } & Non-menopausal & 91 & 50.28 \\
\hline
\end{tabular}

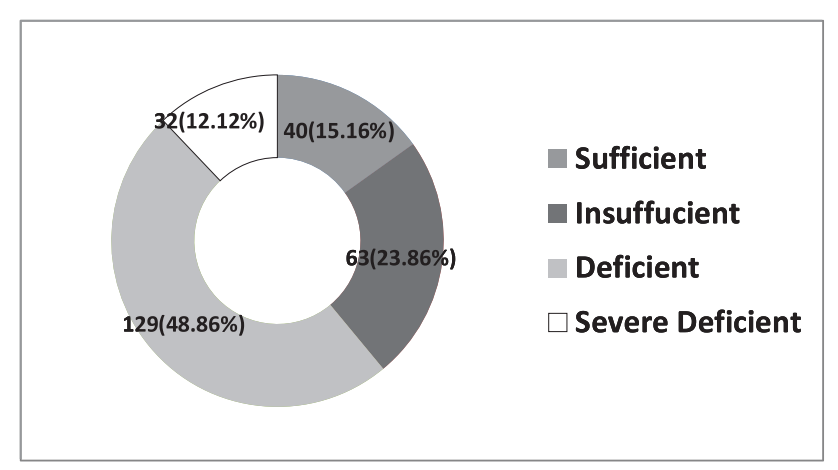

Figure-1: Distribution of hypovitaminosis $D$ among the respondents $(n=264)$ 
Table-II: Relation of socio-demographic variables with mean vitamin $D$ level $(n=264)$

\begin{tabular}{|c|c|c|c|c|c|}
\hline \multicolumn{2}{|c|}{ Variable } & \multirow{3}{*}{\begin{tabular}{|c|}
$\begin{array}{c}\text { Frequency } \\
(\%)\end{array}$ \\
$83(31.44)$ \\
$181(68.56)$ \\
\end{tabular}} & \multirow{3}{*}{\begin{tabular}{|c}
$\begin{array}{c}\text { Mean+ SD vit } \\
\mathrm{D}(\mathrm{nmol} / \mathrm{L})\end{array}$ \\
$50.86+28.61$ \\
$49.60+26.19$
\end{tabular}} & \multirow{3}{*}{\begin{tabular}{|l} 
t Score \\
0.350
\end{tabular}} & \multirow{3}{*}{$\begin{array}{r}p \text { Value } \\
0.726\end{array}$} \\
\hline & Male & & & & \\
\hline Gender & Female & & & & \\
\hline \multirow{2}{*}{ Menopausal state } & Menopausal & $90(49.72)$ & $48.03+28.11$ & \multirow{2}{*}{-1.363} & \multirow{2}{*}{0.007} \\
\hline & Non-me & $91(50.28)$ & $52.32+23.96$ & & \\
\hline \multirow[b]{2}{*}{ Presence of dust } & Present & $43(19.20)$ & $44.88+17.62$ & \multirow[b]{2}{*}{-2.449} & \multirow[b]{2}{*}{0.015} \\
\hline & Absent & $221(80.80)$ & $51.00+28.07$ & & \\
\hline \multirow{2}{*}{ Job pattern } & Office job & $210(79.55)$ & $47.90+24.31$ & \multirow{2}{*}{4.455} & \multirow{2}{*}{0.001} \\
\hline & Outdoor job & $54(20.45)$ & $58.15+31.78$ & & \\
\hline \multirow{2}{*}{ Type of family } & Nuclear & $157(59.47)$ & $51.24+29.23$ & \multirow{2}{*}{0.905} & \multirow{2}{*}{0.366} \\
\hline & Combined & $107(40.53)$ & $48.18+23.14$ & & \\
\hline
\end{tabular}

Table-III: Distribution of hypoviatminosis $D$ by type of living area $(n=264)$

\begin{tabular}{|l|r|r|c|}
\hline \multirow{2}{*}{$\begin{array}{c}\text { Type of living } \\
\text { area }\end{array}$} & \multicolumn{2}{|c|}{ Presence of hypovitaminosis D } & \multirow{2}{*}{$\begin{array}{c}\text { Test of } \\
\text { significance }\end{array}$} \\
\cline { 2 - 3 } & Present & \multicolumn{1}{|c|}{ Absent } & \multirow{2}{*}{$\chi^{2}=7.971$} \\
\hline Town/city & $142(63.39 \%)$ & $34(85.0 \%)$ & \\
\cline { 1 - 2 } Industrial area & $36(16.07 \%)$ & $1(2.5 \%)$ & $\begin{array}{l}\mathrm{df}=2 \\
\mathrm{p}=0.019\end{array}$ \\
\hline Rural area & $46(20.54 \%)$ & $5(12.5 \%)$ & \\
\hline Total & $224(100.0 \%)$ & $40(100.0 \%)$ & \\
\hline
\end{tabular}

Table-IV: Comparison of vitamin $\mathrm{D}$ level by complexion, lifestyle and monthly family income of the respondents $(n=264)$

\begin{tabular}{|c|c|c|c|c|}
\hline \multicolumn{2}{|c|}{ Characteristics } & $\begin{array}{c}\text { Frequency } \\
(\%)\end{array}$ & $\begin{array}{c}\text { Mean + SD } \\
\text { vit D level }\end{array}$ & $\begin{array}{c}\text { One- way } \\
\text { ANOVA }\end{array}$ \\
\hline \multirow{4}{*}{ Complexion } & Fare & 132(50.00) & $54.46+28.24$ & \multirow{4}{*}{$\begin{array}{l}F=5.202 \\
p=0.006\end{array}$} \\
\hline & \begin{tabular}{|l|} 
Medium \\
\end{tabular} & 106(40.15) & $47.49+26.17$ & \\
\hline & Dark & $26(9.85)$ & $42.59+16.79$ & \\
\hline & Total & $264(100.00)$ & $50.01+29.93$ & \\
\hline \multirow{4}{*}{ Lifestyle } & Military & $50(18.94)$ & $56.47+33.11$ & \multirow{4}{*}{$\begin{array}{l}F=2.866 \\
p=0.059\end{array}$} \\
\hline & Civil & $158(59.85)$ & $46.90+25.77$ & \\
\hline & Military s & $56(21.21)$ & $52.95+22.79$ & \\
\hline & \begin{tabular}{|l|} 
Total \\
\end{tabular} & $264(100.00)$ & $50.01+29.93$ & \\
\hline \multirow{5}{*}{$\begin{array}{l}\text { Monthly family income } \\
\text { (Taka) }\end{array}$} & $5001-30000$ & $44(16.66)$ & $46.32+26.29$ & \multirow{5}{*}{$\begin{array}{l}F=2.184 \\
p=0.023\end{array}$} \\
\hline & $30001-60000$ & $68(25.76)$ & $46.61+26.59$ & \\
\hline & $60001-90000$ & $77(29.17)$ & $55.07+34.19$ & \\
\hline & $90001-150000$ & $75(28.41)$ & $52.47+23.84$ & \\
\hline & \begin{tabular}{|l|} 
Total \\
\end{tabular} & $264(100.00)$ & $50.01+29.93$ & \\
\hline
\end{tabular}

\section{Discussion}

The study revealed the mean $\pm S D$ level of vitamin $D$ was $50.01+28.62 \mathrm{nmol} / \mathrm{L}$. The prevalence of Hypovitaminosis D was $84.84 \%$. In 2015, a study was conducted among the female garments workers in Dhamrai under Dhaka district. In that study, the prevalence of Hypovitaminosis D was found $100 \%$ among the lower socioeconomic group and it was $80 \%$ among the average socioeconomic group ${ }^{14}$. Another cross-sectional study conducted by a team of NSU, Dhaka found $88.16 \%$ among the children of 1-6 years of old ${ }^{15}$. International Osteoporosis Foundation in 2009 about high prevalence of Hypovitaminosis $D$ across the different parts of Asia. It was $47 \%$ in Thailand, $49 \%$ in Malaysia, $90 \%$ in Japan and $90 \%$ in South Korea8. In a study in Argentina among the healthy elderly people living at home and found theproportion of hypovitaminosis D was $87 \% 16$. So, it is clear that findings of present study are well-matched with prevalence of previous study conducted home and abroad.
Among the male, the mean Vitamin D level was $50.86+26.93$ $\mathrm{nmol} / \mathrm{L}$ and among female had $49.60+26.19 \mathrm{nmol} / \mathrm{L}$. In a study in India (Tirupati) the mean Serum 25(OH)D was $46.3 \mathrm{nmol} / \mathrm{L}$ among male and $38.7 \mathrm{nmol} / \mathrm{L}$ among the female ${ }^{17}$. A crosssectional study in Vietnam showed the difference between vitamin $D$ level between male and female respondents. There mean 25(OH)D level of male was $81.8 \mathrm{nmol} / \mathrm{L}$ and among the female it was $75.1 \mathrm{nmol} / \mathrm{L}^{18}$. Women have often many potential factors for having lower level of Vitamin $D$. Those are composition of body fat, less exposed to sunlight, less chance of physical activity, dietary constrain in country like Bangladesh. In comparison to other studies searched so far, in this study the margin of gender difference is minimum here. The study had a total 181 female respondents. Among those almost half (90 out 181) of them has already developed menopause. The mean Vitamin D level was a bit higher in the women of childbearing age $(52.32+23.96 \mathrm{nmol} / \mathrm{L})$ than that of post-menopausal women $(48.03+13.07 \mathrm{nmol} / \mathrm{L})(\mathrm{t}, \mathrm{p}<0.01)$. Another study found the strong relation of lower mean vitamin $D$ level among the women of post-menopausal to from women of reproductive age. They observed about $5-8 \%$ decrease of mean vitamin $\mathrm{D}$ level with the increase of age by 10 years ${ }^{19}$.

In this study, the mean value of vitamin $D$ was higher among the respondents of upper socioeconomic status. The proportion of hypovitaminosis D was highest (97.8\%) among the respondents who fall in the income group uptoTk 30,000 per month. But it was $76 \%$ among those who earn more than Tk 90,000 monthly. It was statistically significant. $(p<0.05)$. The role of economic status was found controversial in previous studies. In another study in Bangladesh vitamin D deficiency of premenopausal women was measured among two socioeconomic group ${ }^{20}$. There was clear cut difference in vitamin $D$ level between two groups. Among the women of lower socioeconomic group, the mean vitamin D level was 36.7 $\mathrm{nmol} / \mathrm{L}$, while it was $43.5 \mathrm{nmol} / \mathrm{L}$ among the women of higher socioeconomic group. This type of findings also revealed in a study conducted by team of scientist in Pakistan ${ }^{21}$.

\section{Conclusion}

The prevalence of hypovitaminosis $D$ was too high and sociodemographic determinants have a significant impact on vitamin $D$ level. Effective measures need to be taken at all level to overcome nutritional disorder.The requirement of further study to explore the scenario among the national representative samples is earnestly realized.

\section{References}

1. Islam MZ, Akhtaruzzaman, $M$ and Lamberg-Allardt $C$. Hypovitaminosis $D$ is common in both veiled and nonveiled Bangladeshi women. Asia Pac J Clin Nutr 2006; 15:81-7.

2. Harinarayan CV and Joshi SR. Vitamin D status in India. Its implications and remedial measures. J Assoc Physicians India2009; 57:40-8. 
3. Babu US and Calvo MS. Modern India and the vitamin D dilemma: evidence for the need of a national food fortification program. Mol Nutr Food Res 2010; 54:1134-47.

4. Hyppönen $E$ and Power C. Hypovitaminosis D in British adults at age 45 year: Nationwide cohort study of dietary and lifestyle predictors. Am J Clin Nutr 2007; 85:860-8.

5. Jablonski NG. The evolution of human skin and skin color. Annu Rev Anthropol 2004;33:585-623.

6. Sturm RA. Skin colour and skin cancer - MC1R, the genetic link. Melanoma Res 2002;12:405-16.

7. MacLaughlin J, Holick MF. Aging decreases the capacity of human skin to produce vitamin D3. J Clin Invest 1985;76(4):1536-8.

8. Chailurkit LO, Aekplakorn W and Ongphiphadhanakul B. Regional variation and determinants of vitamin $D$ status in sunshine-abundant Thailand. BMC Public Health 2011; 11:853-8.

9. Ho-Pham LT, Nguyen ND, Lai TQ et al. Vitamin D status and parathyroid hormone in a urban population in Vietnam. Osteoporos Int 2011; 22(1):241-8.

10. Munir J, Birge SJ. Vitamin D Deficiency in Pre- and Postmenopausal Women. The North American Menopause Society. Menopause 2008; 15:584-603.

11. Moy FM. Vitamin D status and its associated factors of freeliving Malay adults in a tropical country, Malaysia. J Photochem Photobiolab 2011; 104:444-8.

12. Agarwal KS, Mughal MZ, Upadhyay $P$ et al. The impact of atmospheric pollution on vitamin $\mathrm{D}$ status of infants and toddlers in Delhi, India.Arch Dis Child 2002;87(2):111-3.

13. Mithal A, Wahl DA, Bonjour JP et al.IOF Committee of Scientific Advisors (CSA) Nutrition Working Group. Global vitamin D status and determinants of hypovitaminosis D. Osteoporosis international 2009; 20(11):1807-20

14. Mahmood S, Rahman M, Biswas SK et al. Vitamin D and parathyroid hormone status in female garment workers: A case-control study in Bangladesh. Bio Med Research International 2017;2017.

15. Zaman S, Hawlader MDH, Biswas A et al. High Prevalence of Vitamin D Deficiency among Bangladeshi Children: An Emerging Public Health Problem. Scientific Research Publishing. Health 2017; 9:1680-88.

16. Oliveri B. High prevalence of vitamin $D$ insufficiency in healthy elderly people living at home in Argentina. Eur J Clin Nutr 2004; 58:337-42.

17. Harinarayan CV, Ramalakshmi T, Prasad UV et al.Vitamin D status in Andhrapradesh: A population based study. Indian J Med Res 2008; 127:211-8.

18. Nguyen ND, Lai TQ, Eisman JA et al. Vitamin D status and parathyroid hormone in a urban population in Vietnam. OsteoporosInt 2001; 22:241-8.

19. Lim SK, Kung AW, Sompongse Set al. Vitamin D inadequacy in postmenopausal women in Eastern Asia. Current Medical Research and Opinion 2008; 24(1):99-106.

20. Islam MZ, Lamberg-Allardt C, Kärkkäinen $M$ et al. Vitamin D deficiency: a concern in premenopausal Bangladeshi women of two socio-economic groups in rural and urban region. European Journal of Clinical Nutrition 2002; 56(1):51.

21. Atiq $M$, Suria $A$, Nizami $S Q$ et al. Vitamin $D$ status of breastfed Pakistani infants. Acta Paediatr 1998; 87:737-40. 